\title{
Content Validation of the Dutch Version of the "Older Patients in Acute Care Survey", an Instrument to Measure the Attitude of Hospital Nurses towards Older Patients
}

\author{
Andrea R. van Schelven', Jeroen Dikken ${ }^{2 *}$, Linda G. M. Sillekens ${ }^{3}$, Dirkje D. Oldenhuis ${ }^{4}$, \\ Marieke J. Schuurmans 5 , Jita G. Hoogerduijn² \\ ${ }^{1}$ Sonneburgh Foundation, Rotterdam, The Netherlands \\ ${ }^{2}$ Research Group Care for the Chronically III, Faculty of Health Care, University of Applied Sciences Utrecht, \\ Utrecht, The Netherlands \\ ${ }^{3}$ Orbis Medical Centre, Sittard-Geleen, The Netherlands \\ ${ }^{4}$ The Hague University of Applied Sciences, The Hague, The Netherlands \\ ${ }^{5}$ Department of Rehabilitation, Nursing Science and Sports, Utrecht University, Utrecht, The Netherlands \\ Email: ${ }^{*}$ jeroen.dikken@hu.nl
}

Received 17 December 2014; accepted 31 December 2014; published 13 January 2015

Copyright (C) 2015 by authors and Scientific Research Publishing Inc.

This work is licensed under the Creative Commons Attribution International License (CC BY).

http://creativecommons.org/licenses/by/4.0/

c) (i) Open Access

\section{Abstract}

Aims and objectives: The aim of this study is to validate the "Older Patients in Acute Care Survey" (OPACS) in the Netherlands. Background: Worldwide the population of older people with multimorbidity increases which results in an increase of older hospitalized patients. Literature shows that nurses have a negative attitude towards older patients. To get insight and improve the attitude of nurses, a validated measurement instrument is needed. The OPACS measures hospital nurses' attitudes towards older patients and has proven good content validity in the USA and good face validity and reliability in Australia. Design: A cross-sectional study. Methods: First the OPACS was translated using forward-backward method and testing clarity of wording with a pilot. Second content validity was determined using "Method Lynn" and clarity of wording and appropriateness for measuring attitude were identified. Results: The OPACS showed acceptable content validity (CVI $\geq 0.78$ ) for 14 items (out of 36) of Section A and 22 items (out of 50) of Section B. The content validity for the entire OPACS was (CVI $=0.62$ ). 89.2\% of the participants scored "clear in wording" and $75.6 \%$ of the participants qualified the OPACS appropriate for measuring attitude. Conclusions: The OPACS has good clarity of wording and good appropriateness for measuring attitude. The content validity is low which makes the current Dutch version not appropriate for measuring attitude of nurses in Dutch hospitals. Relevance to clinical practice: A measurement instrument to

"Corresponding author.

How to cite this paper: van Schelven, A.R., et al. (2015) Content Validation of the Dutch Version of the "Older Patients in Acute Care Survey", an Instrument to Measure the Attitude of Hospital Nurses towards Older Patients. International Journal of Clinical Medicine, 6, 7-18. http://dx.doi.org/10.4236/ijcm.2015.61002 
get insight in the attitude of nurses is a first step to improve a negative attitude. A positive attitude of nurses is important to provide good quality of care to the increasing population older people in hospitals. Working with reliable and validated scales is important. This study gives direction to make the OPACS suitable for the Dutch situation.

\section{Keywords}

\section{Attitude, Nurses, OPACS, Content Validity, Translation}

\section{Introduction}

Worldwide, the population of older people is increasing [1]. In the Netherlands, the number of people aged 65 and over is expected to increase from $16 \%$ of the population in 2011 to $26 \%$ of the population in 2039 [2]. Of these, $20 \%$ have two or more chronic diseases which will increase to one in three in the age of 75 . In other countries high percentages of multimorbidity are also described [3]-[7]. As a result of aging and multimorbidity, more hospital nurses are confronted with older patients and more nurses are needed to provide in this care of the future [8] [9].

A lot of nurses have a negative attitude towards older patients [10] [11]. They are more interested in technical specialties such as intensive care, surgery and emergency than in working in geriatrics, which contributes to less popularity of care for older patients [10]-[13]. However, in intensive care, general surgery care and other medical wards, the number of older patients will increase because of aging and multimorbidity, emphasizing the need for nurses who demonstrate a positive attitude towards older patients [5] [6] [8] [9].

Attitude is described as the way a person thinks about something or someone and is consisted of a behavioral, emotional and cognitive component [14]. The behavioral component implies the intention to behave regarding the attitude object. The emotional component implies a person's liking or disliking, based on feelings. The cognitive component implies knowledge and value of a phenomenon. These three components influence each other and ultimately determine the attitude of nurses [14] [15].

The negative attitude towards older patients is caused by the association with deterioration of health, decreased mobility and declining mental state and often a negative experience with older people [16] [17]. Research suggests that there is also a lack of geriatric knowledge. Nurses have insufficiently focused on multiple geriatric health problems among older people. The care of older patients requires a high level of expertise because of multipathology, polypharmacy and behavioral changes [10] [16]-[18]. Ultimately the negative attitude of nurses will have a negative impact on the quality of care and on the quality of life of older patients [12] [18].

\section{Background}

To improve the attitude of nurses, healthcare providers first need to understand the current attitude [9], which can be achieved by measuring attitude using a measurement scale with good clinimetric qualities [19] [20]. In the literature a number of measurement scales are known [12] [21]-[23]. Only one scale, however, measures the behavioral, emotional and cognitive component of attitude. This is the "Older Patients in Acute Care Survey" (OPACS) [9] [11] [21].

The OPACS consist of two scales. Section A measures practical experience (36 items) and Section B measures general opinions and knowledge of older patient's needs (50 items). The items in both Sections A and B consist of thirteen different aspects influencing the nursing care of older patients in the hospital: 1) ageist stereotypes; 2) older patients in the acute care setting; 3) ageing-related issues; 4) communication with older patients; 5) admitting an older patient; 6) discharge planning; 7) decision making; 8) medications; 9) pain management; 10) psychological status; 11) hygiene and ADL; 12) continence; and 13) mobility. Items of Section A and B are answered by a five point Likert scale $(1=$ never and $5=$ very frequent) [9] [21]. The OPACS is developed in Australia and validated in the United States. The Australian and United States versions both showed adequate clinimetric qualities. The Australian version showed good face validity and high reliability (Kappa 0.76) [21]. The United States version had a high content validity (CVI 0.92) [9].

Before the OPACS can be applied in countries other than Australia or the United States, the OPACS should 
be translated into the language of that country and the validity and reliability of this version of OPACS should be examined. Cultural norms and values play important roles in attitude, and a measurement scale should be validated when it is used in different countries or cultures. Determining the content validity is a critical important first step in this validation process [24].

The aim of this study is to determine the content validity of the OPACS in the Dutch situation after translation of the measurement scale into the Dutch language.

\section{Methods}

The study consisted of a two-phase process: translation of OPACS into Dutch, and determining the content validity of OPACS into the Dutch healthcare system setting.

\subsection{Translation of OPACS}

For translating the OPACS into the Dutch language, the United States version was chosen because the American English usage is more familiar to Dutch translators than Australian English usage. Both Section A and Section B were translated into the Dutch language using the forward-backward translation method (Figure 1) [25] [26].

Two independent bilingual persons translated the OPACS into the Dutch language. These translations were compared with each other and with the English version of the OPACS and finally determined by two researchers. The Dutch translation was translated back into the English source language by one translator who did not see the original wording. The English back-translation was compared with the first English version to detect possible alterations in meaning. Ambiguities and discrepancies were discussed by two researchers until consensus was achieved.

A pilot among five registered nurses, all working with older patients, was used to test the clarity of wording of all items of the Dutch OPACS using labels $0=$ not clear and $1=$ clear.

\subsection{Validation}

The content validity of the OPACS was studied using a cross-sectional design.

\subsection{Data Collection}

A panel of Dutch experts in geriatric nursing was contacted from the professional network of the two researchers and included teachers, geriatric nurses and geriatric experts from the Geriatric Network of the Dutch Nurses Association. Inclusion criteria were: be able to speak, read and write Dutch, a bachelor degree in nursing, working as a registered nurse in geriatrics for at least five years or worked in a profession that requires knowledge of geriatric nursing for at least five years.

All participants received an invitation letter with extended information, response instructions, the Dutch OPACS and an informed consent form. All respondents, signed and returned the informed consent-form before participating in the study.

Content validity was tested using a score of degree of relevance using a four-point Likert scale ( 1 = not relevant and 4 = highly relevant) shown in Figure 2 [27]. The clarity of wording and appropriateness for measuring

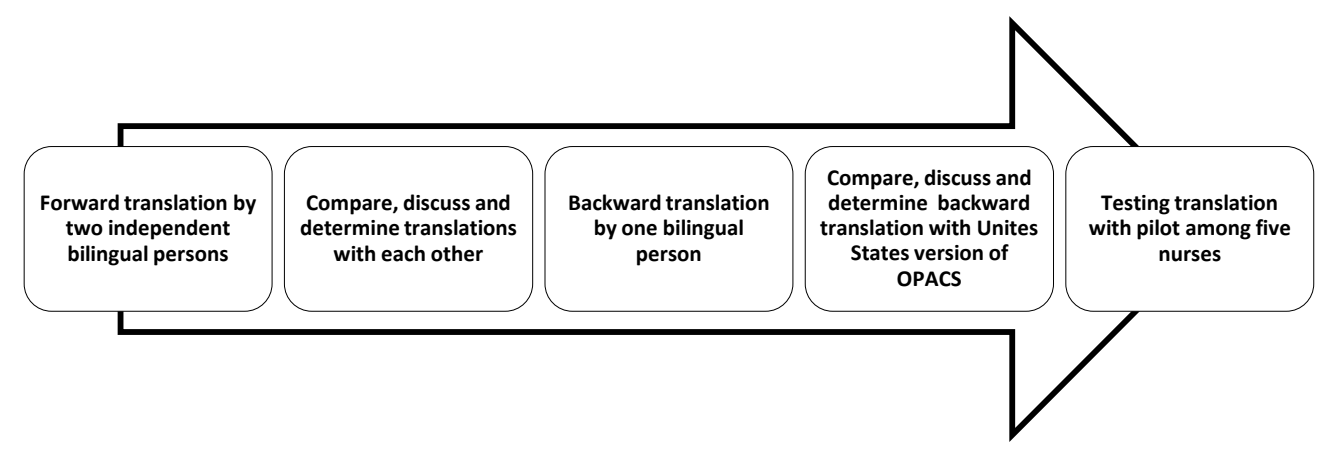

Figure 1. Method translation. Ambiguities and discrepancies were discussed whereby consensus was achieved. 


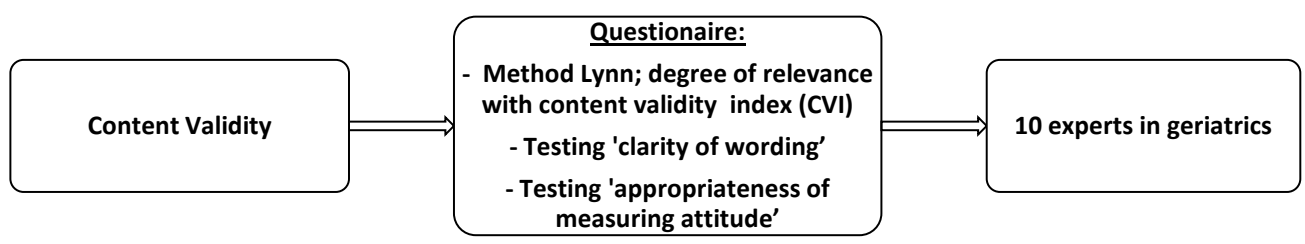

Figure 2. Method content validation.

attitude was also determined using a two-point Likert scale $(0=$ not clear/not appropriate and $1=$ clear/appropriate $)$.

\subsection{Analysis}

Data were analyzed using Statistical Package for Social Sciences (SPSS) version 18.0 [28].

For the degree of relevance scores the items were dichotomized by summarizing score 1 and 2 (not relevant) and summarizing score 3 and 4 (relevant). The Individual-Content Validity Index (I-CVI) was the result of the scores of one item divided by the number of participants. For an individual question to be considered relevant, its I-CVI should be $\geq 0.78$ [27]. The Scale-Content Validity Index (S-CVI) is the mean of all I-CVI. For the entire scale to be considered relevant, the S-CVI should be $\geq 0.90$ [27].

Percentage and mean were used for analyzing the variable clarity of wording and variable appropriateness for measuring attitude.

If an expert did not grade a question, the missing value was imputed in two different datasets based on the original database whereby the worst possible score and the best possible score were imputed. Differences between original, worst case and best case database were analyzed with the Kruskal Wallis test to decide if imputation was reliable and which dataset should be used for further analyzing [28].

\section{Results}

\subsection{Translation of OPACS}

Small differences and errors were found between forward and backward translation on 24 (out of 36) items of Section A and 40 (out of 50) items of Section B. Nine (out of 36) items of Section A and six (out of 50) items of Section B were completely corrected. Three (out of 36) items of Section A were unchanged and in Section B four items (out of 50).

All participants of the translation clarity pilot evaluation returned the questionnaire $(n=5)$ with no missing values. The five participants made 19 suggestions for improvement for Section A and 36 suggestions for Section B. These suggestions included changes in words and sentence structure. The authors adopted 19 of the suggested changes for the first Dutch version of OPACS which was used for content validity.

\subsection{Validation}

Ten participants were included in the validity portion of the study. Nine participants completed the demographics, one participant completed the questionnaire without completing the demographics section (Table 1). The participant demographic showed that five participants were educated at Master of Science-level. The average length of time working in healthcare was 24 years (SD 8.7; range 9 - 32). Seven participants worked in geriatric nursing and two were lecturers in geriatric nursing.

All missing values of the outcome variables "relevance", "clarity of wording”, "appropriateness for measuring attitude" were excluded from analyzing because imputation was not relevant: The Kruskal Wallis test showed no significant difference $(K \geq 0.15)$ which means that there was no difference between the original, the worst case database and best case database.

The degree of relevance for the entire OPACS was S-CVI $=0.62$. The score for Section A was S-CVI $=0.61$ and the score for Section B was S-CVI = 0.64 (Table 2). Content validity for individual items (I-CVI): 6 items of Section A and 5 items of Section B showed an I-CVI $=1.00$. A total of 14 out of 36 items of Section A and 22 of 50 items of Section B showed an I-CVI $\geq 0.78$ (Table 3). 
Table 1. Demographic characteristics $(n=10)$.

\begin{tabular}{|c|c|}
\hline & $\mathbf{n}$ \\
\hline Age & $44.11(9.28)^{*}$ \\
\hline \multicolumn{2}{|l|}{ Gender } \\
\hline Female & 8 \\
\hline \multicolumn{2}{|l|}{ Highest Qualification } \\
\hline Bachelor in Nursing & 1 \\
\hline Post-Bachelor in Nursing & 2 \\
\hline Master of Science in Nursing & 5 \\
\hline Different & 1 \\
\hline \multicolumn{2}{|l|}{ Current Area of Practice } \\
\hline Geriatric Nursing & 6 \\
\hline Teaching on Bachelor Level & 2 \\
\hline Other in Healthcare & 1 \\
\hline \multicolumn{2}{|l|}{ Job } \\
\hline Geriatric Nursing Specialist & 4 \\
\hline Teaching Geriatrics & 2 \\
\hline Geriatric Nursing Expert & 1 \\
\hline Nurse Practitioner & 1 \\
\hline Geriatric Nurse \& Student Nursing Science & 1 \\
\hline \multicolumn{2}{|l|}{ Employment } \\
\hline Fulltime & 5 \\
\hline Post Registration Experience & $24.22(8.70)^{*}$ \\
\hline Post Registration Experience Current Area of Practice & $6.22(3.84)^{*}$ \\
\hline
\end{tabular}

( $\mathrm{n}=9$ as result of one missing value); ${ }^{*}$ Mean (SD).

Table 2. Content validity index.

Relevance S-CVI (SD)
OPACS Section A (Item 1 - 36)
$0.61(0.31)$
OPACS Section B (Item 1 - 50)
$0.64(0.25)$
OPACS Section A (Item 1 - 36) and B (Item 1 - 50)
$0.62(0.28)$

The entire OPACS was scored as clear in wording by $89.20 \%$ of the participants. Section A was scored as clear in wording by $92.07 \%$ of the participants and section B $87.13 \%$ of the participants (Table 4). Two individual items scored low on clarity in wording by $\leq 30 \%$ of the participants.

The entire OPACS was scored as appropriate for measuring attitude by $75.55 \%$ of the participants. Section A was scored as appropriate according to $73.64 \%$ of the participants and Section B by $76.93 \%$ of the participants (Table 3). Eight individual items scored low on appropriateness for measuring attitude by $\leq 30 \%$ of the participants. 
Table 3. Items of the OPACS with an acceptable I-CVI.

\begin{tabular}{|c|c|c|}
\hline & OPACS Section A & $\begin{array}{c}\text { Relevance } \\
\text { I-CVI }\end{array}$ \\
\hline Item 01 & I find older patients difficult to care for. & 0.90 \\
\hline Item 02 & I find older patients more time consuming than younger patients. & 0.90 \\
\hline Item 11 & I allow extra time when I am going to admit an older patient. & 1.00 \\
\hline Item 12 & I find it more difficult to obtain a comprehensive health history from an older patient than a younger patient. & 0.80 \\
\hline Item 13 & I use information gathered during an older patient's admission to plan their care. & 1.00 \\
\hline Item 14 & I use a health assessment tool specifically designed for older patients. & 1.00 \\
\hline Item 15 & I find it necessary to watch confused older patients closely. & 1.00 \\
\hline Item 16 & I am more likely to use some form of restraint on an older patient than on a younger patient. & 0.80 \\
\hline Item 23 & I involve an older patient's family/care-giver in their care. & 0.90 \\
\hline Item 24 & I explain medications more than once to older patients to ensure understanding. & 0.90 \\
\hline Item 32 & I involve older patients in decision-making relating to their health. & 1.00 \\
\hline Item 33 & I encourage older patients to maintain their independence while in the hospital. & 1.00 \\
\hline Item 34 & I begin discharge planning earlier in an older patient's stay than in a younger patient's stay. & 0.80 \\
\hline \multirow{2}{*}{ Item 35} & I allow more time to prepare an older patient for discharge than a younger patient. & 0.80 \\
\hline & OPACS Section B & $\begin{array}{c}\text { Relevance } \\
\text { I-CVI }\end{array}$ \\
\hline Item 01 & I like to care for older patients. & 1.00 \\
\hline Item 06 & Older patients are a nuisance to care for. & 0.80 \\
\hline Item 09 & Older patients do not know the actions and interactions of their medications. & 0.80 \\
\hline Item 12 & Older patients become addicted to sleeping medications easily. & 0.80 \\
\hline Item 18 & An older patient's family/care-giver should be involved in their care. & 1.00 \\
\hline Item 19 & Older patients, if not confused, are capable of making decisions about their care. & 1.00 \\
\hline Item 20 & Family member/care-givers should be involved in the decision making process for all older patients. & 0.90 \\
\hline Item 21 & Rehabilitation of older patients is part of the doctors'/nurses' role. & 0.80 \\
\hline Item 22 & Older patients should have a say in whether they receive life-sustaining treatments. & 1.00 \\
\hline Item 23 & Too many older patients receive life-sustaining treatment. & 0.78 \\
\hline Item 24 & Older patients have more discharge problems than do younger patients. & 0.80 \\
\hline Item 25 & At the time of discharge older patients are likely to be more dependent than younger patients. & 0.80 \\
\hline Item 27 & Older patients have extensive lengths of stay and take up beds that could be used for sicker patients. & 0.80 \\
\hline Item 28 & There are too many older patients in acute care hospitals. & 0.90 \\
\hline Item 29 & It would be a good idea for all hospitals to have an acute geriatric unit. & 0.80 \\
\hline Item 32 & Older patients become confused in a new setting. & 0.80 \\
\hline Item 40 & Older patients are more likely to require assistance with mobility than younger patients. & 0.90 \\
\hline Item 45 & Older patients’ health problems are often incurable. & 0.90 \\
\hline Item 47 & Older patients become confused after operations/procedures. & 1.00 \\
\hline Item 48 & Older patients are more likely to develop post-operative complications. & 0.90 \\
\hline Item 49 & Older patients are particularly prone to nosocomial infections. & 0.80 \\
\hline Item 50 & Early discharge is difficult to achieve with older patients. & 0.80 \\
\hline
\end{tabular}


Table 4. Clarity of wording \& appropriateness.

\begin{tabular}{ccc}
\hline & $\begin{array}{c}\text { Clarity of Dutch Wording } \\
\text { mean \%, (SD) }\end{array}$ & $\begin{array}{c}\text { Appropriateness for Measure Attitude } \\
\text { mean \% (SD) }\end{array}$ \\
\hline OPACS Section A (Item 1 - 36) & $92.07(16.65)$ & $73.64(25.75)$ \\
OPACS Section B (Item 1 - 50) & $87.13(14.22)$ & $76.93(21.08)$ \\
OPACS Section A (Item 1 - 36) and B (Item 1 - 50) & $89.20(15.37)$ & $75.55(23.06)$ \\
\hline
\end{tabular}

\section{Discussion}

This study presents the production and validation of a Dutch version of OPACS (see Appendix 1). The pilot showed a good translation of OPACS into Dutch.

Content validity was determined by method Lynn which is commonly used and well described in the literature [27]. According to this method, an optimal content validity should be S-CVI $\geq 0.90$. This study did not meet this criterion (S-CVI $=0.62$ ) which means that this version of the Dutch OPACS is not yet adequate for use in the Dutch health care system. However, the entire OPACS scored well on clarity of wording $(89.20 \%$ of participants) meaning that most items are correctly formulated. The results for appropriateness for measuring attitude were also good for the entire OPACS (75.55\% of participants) meaning that experts think that multiple items seem to be adequate for measuring the attitude of nurses. Analysis for the entire scale compared to section $\mathrm{A}$ and section B shows the same results.

The results of this study are incongruent with the results of Malmgreen (2009), who found high content validity of the Unites States version of OPACS (entire scale CVI $=0.92$; Section A CVI $=0.92$; Section B CVI $=$ 0.97). The content validity of the Dutch version of OPACS is low (entire scale CVI $=0.62$; Section A CVI $=$ 0.61 ; Section B CVI $=0.64$ ) when evaluated by Dutch experts in geriatrics. These large differences between the content validity of the English and Dutch versions might be caused by cultural differences between the two settings. The differences between the assessed validity of the two versions could also be caused by the number of participants in each study. Content validity should be assessed by between five and ten participants [27]. This study used ten participants, where Malmgreen (2009) used a smaller number of participants $(n=4)$. A smaller number of participants increases the coincidence of like-minded outcomes which has an influence on the statistical outcome using method Lynn.

Limitations of this study should be taken into account. During the translation the two researchers discussed many items which showed that certain items were difficult to translate into the Dutch language. The Dutch language does not have sufficient specific and unambiguous words for certain translations such as "I tend to ..." which might be culture related. It also explains the number of changed items and might had an effect on the translation [26]. However, consensus was always achieved. Furthermore both the pilot and the results of this study showed a good translation by showing a good clarity of wording and appropriateness for measuring attitude.

\section{Conclusion}

In this study, the English OPACS was translated into Dutch, resulting in the first non-English version of this instrument measuring the attitude of nurses towards older hospitalized patients. The pilot of the translated OPACS confirmed that is was a good translation from the American-English version. When the instrument was assessed by a panel of Dutch experts in geriatric patients care, the content validity measurement showed a low score for relevance, but a high score for clarity of wording and appropriateness for measuring attitude for the entire scale, Section A and Section B. The current Dutch translation of OPACS does not meet all criteria for good content validity and does not justify the use of this Dutch version of OPACS.

\section{Relevance to Clinical Practice}

Measuring attitude of nurses is important to provide good quality of care to the increasing population of older hospitalized patients. Only with a good attitude it is possible that the care of nurses will meet the nursing needs of older patients. That is why the attitude of nurses should be measured. In this process, it is important to work with reliable and valid measurement scales. This study shows that the Dutch version of OPACS is not yet appli- 
cable for clinical practice, however, it is promising. This study gives an overall direction to optimize and improve the content of OPACS. Further research is necessary to determine the most appropriate items to measure the cognitive, emotional and behavioral component of attitude of nurses towards older patients in the Dutch setting. Finally, future research should be focusing on further assessing the validity and reliability of the improved version of the Dutch OPACS.

\section{Conflict of Interest}

None declared.

\section{Contributions}

AvS, MS and JH conceived the original idea for the study. AvS, LS, DO and JH designed the study protocol. AvS and JH executed the study and executed the statistical analyses. All authors were involved in interpreting the data. AvS, JD and JH drafted the manuscript; all other authors read the manuscript critically for important intellectual content.

\section{Acknowledgements}

We thank Drs. C. L. J. J. Kruitwagen for his statistical help and advice during the study.

\section{References}

[1] World Health Organisation (2012) What Are the Public Health Implications of Global Ageing? http://www.who.int/features/qa/42/en/index.html

[2] RIVM (2012) Aging, Wat Are the Most Important Expectations for the Future? http://www.nationaalkompas.nl/bevolking/vergrijzing/toekomst

[3] RIVM (2012) Older People: Chronic Illness and Multimorbidity. http://www.nationaalkompas.nl/thema-s/ouderen/gezondheid-en-ziekte/ziekten-en-aandoeningen/chronische-ziekten-en -multimorbiditeit/chronische-ziekten-en-multimorbiditeit/

[4] Narain, P., Rubenstein, L., Wieland, G., Rosbrook, B., Strome, L., Pietruszka, F., et al. (1988) Predictors of Immediate and 6-Month Outcomes in Hospitalized Elderly Patients. The Importance of Functional Status. Journal of the American Geriatrics Society, 36, 775-783.

[5] Marengoni, A., Angleman, S., Melis, R., Mangialasche, F., Karp, A., Garmen, A., et al. (2011) Aging with Multimorbidity: A Systematic Review of the Literature. Ageing Research Reviews, 10, 430-439. http://dx.doi.org/10.1016/j.arr.2011.03.003

[6] Marengoni, A., Winblad, B., Karp, A. and Fratiglioni, L. (2008) Prevalence of Chronic Diseases and Multimorbidity among the Elderly Population in Sweden. American Journal of Public Health, 98, 1198-1200.

http://dx.doi.org/10.2105/AJPH.2007.121137

[7] Fortin, M., Bravo, G., Hudon, C., Vanasse, A. and Lapointe, L. (2005) Prevalence of Multimorbidity among Adults Seen in Family Practice. Annals of Family Medicine, 3, 223-228. http://dx.doi.org/10.1370/afm.272

[8] Goncalves, D.C. (2009) From Loving Grandma to Working with Older Adults: Promoting Positive Attitudes towards Aging. Educational Gerontology, 35, 202-225.

[9] Malmgreen, C., Graham, P.L., Shortridge-Baggett, L.M., Courtney, M. and Walsh, A. (2009) Establishing Content Validity of a Survey Research Instrument: The Older Patients in Acute Care Survey-United States. Journal for Nurses in Staff Development, 25, E14-E18. http://dx.doi.org/10.1097/NND.0b013e3181a689b4

[10] Higgins, I., Van der Riet, P., Slater, L. and Peek, C. (2007) The Negative Attitudes of Nurses towards Older Patients in the Acute Hospital Setting: A Qualitative Descriptive Study. Contemporary Nurse, 26, 225-237. http://dx.doi.org/10.5172/conu.2007.26.2.225

[11] Courtney, M., Tong, S. and Walsh, A. (2000) Acute-Care Nurses' Attitudes towards Older Patients: A Literature Review. International Journal of Nursing Practice, 6, 62-69.

[12] Küçükgüçlü, Ö., Mert, H. and Akpinar, B. (2011) Reliability and Validity of Turkish Version of Attitudes toward Old People Scale. Journal of Clinical Nursing, 20, 3196-3203. http://dx.doi.org/10.1111/j.1365-2702.2011.03764.x

[13] Baumbusch, J., Dahlke, S. and Phinney, A. (2012) Nursing Students’ Knowledge and Beliefs about Care of Older Adults in a Shifting Context of Nursing Education. Journal of Advanced Nursing, 68, 2550-2558. 
http://dx.doi.org/10.1111/j.1365-2648.2012.05958.x

[14] Dawson, K.P. (1992) Attitude and Assessment in Nurse Education. Journal of Advanced Nursing, 17, 473-479.

[15] Bohner, G. and Wanke, M. (2002) Attitudes and Attitude Change. Psychology Press, Hove.

[16] Jansen, D., Winifred, A. and Morse, W.A. (2004) Positively Influencing Student Nurse Attitudes toward Caring for Elders: Results of a Curriculum Assessment Study. Gerontology \& Geriatrics Education, 25, 1-14.

[17] Chen, S. and Walsh, S.M. (2009) Effect of a Creative-Bonding Intervention on Taiwanese Nursing Students' SelfTranscendence and Attitudes toward Elders. Research in Nursing \& Health, 32, 204-216. http://dx.doi.org/10.1002/nur.20310

[18] Gallagher, S., Bennett, K.M. and Halford, J.C.G. (2006) A Comparison of Acute and Long-Term Health-Care Personnel's Attitudes towards Older Adults. International Journal of Nursing Practice, 12, 273-279. http://dx.doi.org/10.1111/j.1440-172X.2006.00582.x

[19] Terwee, C.B., Bot, S.D.M., de Boer, M.R., van der Windt, D.A.W.M., Knol, D.L., Dekker, J., et al. (2007) Quality Criteria Were Proposed for Measurement Properties of Health Status Questionnaires. Journal of Clinical Epidemiology, 60, 34-42.

[20] Streiner, D. and Norman, G.R. (2008) Health Measurement Scales a Practical Guide to Their Development and Use. 4th Edition, Oxford University Press, New York.

[21] Courtney, M., Tong, S. and Walsh, A. (2000) Older Patients in Acute Care Setting: Rural and Metropolitan Nurses’ Knowledge, Attitudes and Practices. Australian Journal of Rural Health, 8, 94-102. http://dx.doi.org/10.1046/j.1440-1584.2000.00256.x

[22] Soderhamn, O., Lindencrona, C. and Gustavsson, S.M. (2001) Attitudes toward Older People among Nursing Students and Registered Nurses in Sweden. Nurse Education Today, 21, 225-229.

[23] Lambrinou, E., Sourtzi, P., Kalokerinou, A. and Lemonidou, C. (2005) Reliability and Validity of the Greek Version of Kogan's Old People Scale. Journal of Clinical Nursing, 14, 1241-1247. http://dx.doi.org/10.1111/j.1365-2702.2005.01229.x

[24] Polit, D.F., Beck, C.T. and Owen, S.V. (2007) Is the CVI an Acceptable Indicator of Content Validity? Appraisal and Recommendations. Research in Nursing \& Health, 30, 459-467. http://dx.doi.org/10.1002/nur.20199

[25] Polit, D.F. and Beck, C.T. (2008) Nursing Research, Generating and Assessing Evidence for Nursing Practice. 8th Edition, Wolters Kluwer Health/Lippincott Williams \& Wilkins, Philadelphia.

[26] Maneesriwongul, W. and Dixon, J.K. (2004) Instrument Translation Process: A Methods Review. Journal of Advanced Nursing, 48, 175-186.

[27] Lynn, M.R. (1986) Determination and Quantification of Content Validity. Nursing Research, 35, 382-385. http://dx.doi.org/10.1097/00006199-198611000-00017

[28] Pallant, J. (2007) SPSS Survival Manual: A Step by Step Guide to Data Analysis Using SPSS for Windows. 3rd Edition, McGraw Hill Open University Press, New York. 
Appendix 1 Dutch Version of OPACS (OPACS NL)

OPACS Deel A: Praktische Ervaringen.

\begin{tabular}{lll}
\hline & Items & Zeer \\
vaak
\end{tabular}

1 Ik vind het moeilijk om voor oudere patiënten te zorgen

2 Ik vind dat oudere patiënten meer tijd in beslag nemen dan jongere patiënten

3 Ik vind het nodig oudere patiënten nauwkeuriger te observeren dan jongere patiënten

4 Ik zou eerder eenvoudige taal gebruiken bij een oudere patiënt dan bij een jongere patiënt

5 Ik heb de neiging langzamer te praten wanneer ik met een oudere patiënt spreek

6 Ik heb de neiging harder te praten wanneer ik met een oudere patiënt spreek

7 Ik ben geneigd socialer te praten met een oudere patiënt

8 Ik ben geneigd socialer te praten met een jongere patiënt

9 Ik zou eerder troetelwoorden (bv. liefje, schatje) gebruiken bij oudere vrouwelijke patiënten dan bij

9 jongere vrouwelijke patiënten

10 Ik zou eerder troetelwoorden (bv. opa, schat) gebruiken bij oudere mannelijke patiënten dan bij jongere 10 mannelijke patiënten

$11 \mathrm{Ik}$ neem extra de tijd wanneer ik een oudere patiënt opneem

12 Ik vind het moeilijker een uitgebreide gezondheidsanamnese te verkrijgen bij een oudere patiënt dan bij een jongere patiënt

13 De informatie die ik gekregen heb bij de opname gebruik ik om de zorg voor de oudere patiënt te plannen

14 Ik gebruik een gezondheidsanamnese speciaal ontworpen voor oudere patiënten

$15 \mathrm{Ik}$ vind het nodig om verwarde oudere patiënten nauwkeurig in de gaten te houden

16 Ik zou eerder enige vorm van vrijheidsbeperkende maatregelen gebruiken bij een oudere patiënt dan bij

16 een jongere patiënt

17 Ik biedt vaker hulp bij persoonlijke hygiëne aan oudere patiënten dan aan jongere patiënten

18 Ik vraag vaker aan oudere patiënten of zij ondersteuning bij de activiteiten van het dagelijks leven

18 nodig hebben dan aan jongere patiënten

19 Ik heb moeite om de pols van oudere patiënten te voelen

20 Ik vraag jongere patiënten of ze incontinentieproblemen hebben

21 Ik vraag oudere patiënten of ze incontinentieproblemen hebben

22 Ik betrek de familie/ mantelzorger bij de zorg van een jongere patiënt

23 Ik betrek de familie/ mantelzorger bij de zorg van een oudere patiënt

24 Aan oudere patiënten geeft ik meer dan eens uitleg over hun medicatie om er zeker van te zijn dat ze

24 het begrijpen

25 Ik zou aan een oudere patient minder snel zelfmedicatie (bv. pijn-pomp, insulinepomp, inhaler) in het

25 ziekenhuis aanmoedigen dan aan een jongere patiënt

26 Ik vraag vaker aan oudere patiënten of ze pijn hebben dan aan jongere patiënten

27 Ik vraag vaker aan oudere patiënten of ze pijnstilling nodig hebben dan aan jongere patiënten

28 Ik controleer vaker bij oudere patiënten of ze de werking van de pijn-pomp (PCA) begrijpen dan bij 8 jongere patiënten

29 Ik zou eerder aan een oudere patiënt vragen of ze iets willen hebben om te slapen dan aan een jongere patiënt

30 Ik zou eerder aan een oudere patiënt vragen of deze contact wil met een geestelijk verzorger dan aan

30 een jongere patiënt

31 Ik betrek jongere patiënten bij besluitvorming met betrekking tot hun gezondheid

32 Ik betrek oudere patiënten bij besluitvorming met betrekking tot hun gezondheid

33 Ik moedig oudere patiënten aan hun onafhankelijkheid te behouden terwijl ze in het ziekenhuis zijn

34 Bij de opname van een oudere patiënt begin ik eerder met de ontslagplanning dan bij de opname van

34 een jongere patiënt

35 Ik neem meer tijd om het ontslag bij een oudere patiënt voor te bereiden dan bij een jongere patiënt

36 Ik vind het gemakkelijker met de dood van een oudere patiënt om te gaan dan met de dood van een jongere patiënt 
OPACS Deel B: Algemene Opvattingen.

\section{Items}

Nooit Zelden Soms Vaak Zeer vaak

1 Ik zorg graag voor oudere patiënten

2 Oudere patiënten passen zich gemakkelijk aan aan de patiëntenrol

3 Oudere patiënten hebben vergelijkbare behoeften in het ziekenhuis

4 Oudere patiënten zijn verward

5 Oudere patiënten doen alsof ze je niet horen

6 Oudere patiënten zijn een last om voor te zorgen

7 Oudere patiënten zijn eerder depressief dan jongere patiënten

8 Oudere patiënten moeten speciale diëten volgen

9 Oudere patiënten kennen de werking en bijwerkingen van hun medicijnen niet

10 Oudere patiënten hebben minder pijnstilling nodig dan jongere patiënten

11 Oudere patiënten raken minder snel verslaafd aan pijnstillers dan jongere patiënten

12 Oudere patiënten raken gemakkelijk verslaafd aan slaapmiddelen

13 Patiënten die incontinent zijn, zijn lastig.

14 Urine-incontinentie hoort bij het verouderingsproces

15 Oudere patiënten maken zich meer zorgen om hun darmwerking dan jongere patiënten

16 Oudere patiënten schamen zich wanneer hun lichaam ontbloot is

17 Jongere patiënten schamen zich wanneer hun lichaam ontbloot is

18 Familieleden/mantelzorgers zouden betrokken moeten zijn bij de zorg van oudere patiënten

19 Oudere patiënten die niet verward zijn, zijn in staat beslissingen te nemen over hun zorg.

20 Bij alle oudere patiënten zouden familieleden /mantelzorgers betrokken moeten zijn bij het besluitvormingsproces

21 Revalidatie van oudere patiënten is onderdeel van de rol van artsen/ verpleegkundigen

22 Oudere patiënten zouden moeten meebeslissen of ze essentiële behandelingen gericht op levensbehoud willen ondergaan

23 Te veel oudere patiënten krijgen essentiële behandelingen gericht op levensonderhoud

24 Oudere patiënten hebben meer problemen bij ontslag dan jongere patiënten

25 Bij hun ontslag is het waarschijnlijker dat oudere patiënten meer afhankelijk zijn dan jongere patiënten

26 Oudere patiënten hebben plaatsing in langdurige zorg nodig na ontslag uit het ziekenhuis

27 Oudere patiënten hebben een langere opnameduur en bezetten bedden die voor ziekere patiënten gebruikt zouden kunnen worden

28 Er liggen teveel oudere patiënten in de ziekenhuizen

29 Het zou een goed idee zijn om in alle ziekenhuizen een geriatrische afdeling te hebben

30 Oudere patiënten zijn geneigd om minder angstig te zijn bij een opname dan jongere patiënten

31 Oudere patiënten gebruiken bij opname in het ziekenhuis meestal meer medicijnen dan jongere patiënten

32 Oudere patiënten raken in de war in een nieuwe omgeving

33 Oudere patiënten voelen zich geïsoleerd in het ziekenhuis

34 In het ziekenhuis zullen oudere patiënten vaker omgaan met andere oudere patiënten

35 In het ziekenhuis zijn eten en drinken de meest voorkomende activiteiten voor oudere patiënten

36 Oudere patiënten hebben gezonde eetgewoontes 


\section{Continued}

37 Oudere patiënten hebben meer huidproblemen dan jongere patiënten

38 Oudere patiënten hebben een verminderde perifere circulatie

39 Een slechte voedingstoestand hoort bij het verouderingsproces

40 Het is waarschijnlijker dat oudere patiënten ondersteuning nodig hebben bij mobiliteit dan jongere patiënten

41 Veel oudere patiënten hebben stijve gewrichten

42 Oudere patiënten lopen minder risico op vallen dan jongere

43 Oudere patiënten hebben de neiging om zorgverleners niet te vertellen dat ze incontinent zijn

44 In het ziekenhuis ervaren oudere patiënten een verandering van het ontlastingspatroon

45 De gezondheidsproblemen van oudere patiënten zijn vaak niet te genezen

46 Het is waarschijnlijker dat oudere patiënten (open) chirurgische ingrepen hebben dan laparoscopische chirurgie

47 Oudere patiënten raken verward na operaties/procedures

48 Oudere patiënten hebben de neiging vaker postoperatieve complicaties te ontwikkelen

49 Oudere patiënten zijn bijzonder vatbaar voor nosocomiale infecties (ziekenhuisinfecties)

50 Een vroeg ontslag is moeilijk te realiseren bij oudere patiënten 
Scientific Research Publishing (SCIRP) is one of the largest Open Access journal publishers. It is currently publishing more than 200 open access, online, peer-reviewed journals covering a wide range of academic disciplines. SCIRP serves the worldwide academic communities and contributes to the progress and application of science with its publication.

Other selected journals from SCIRP are listed as below. Submit your manuscript to us via either submit@scirp.org or Online Submission Portal.
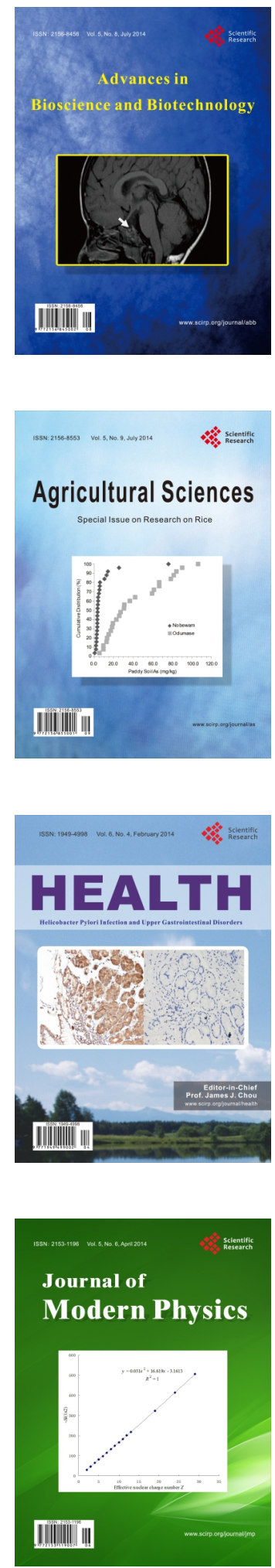
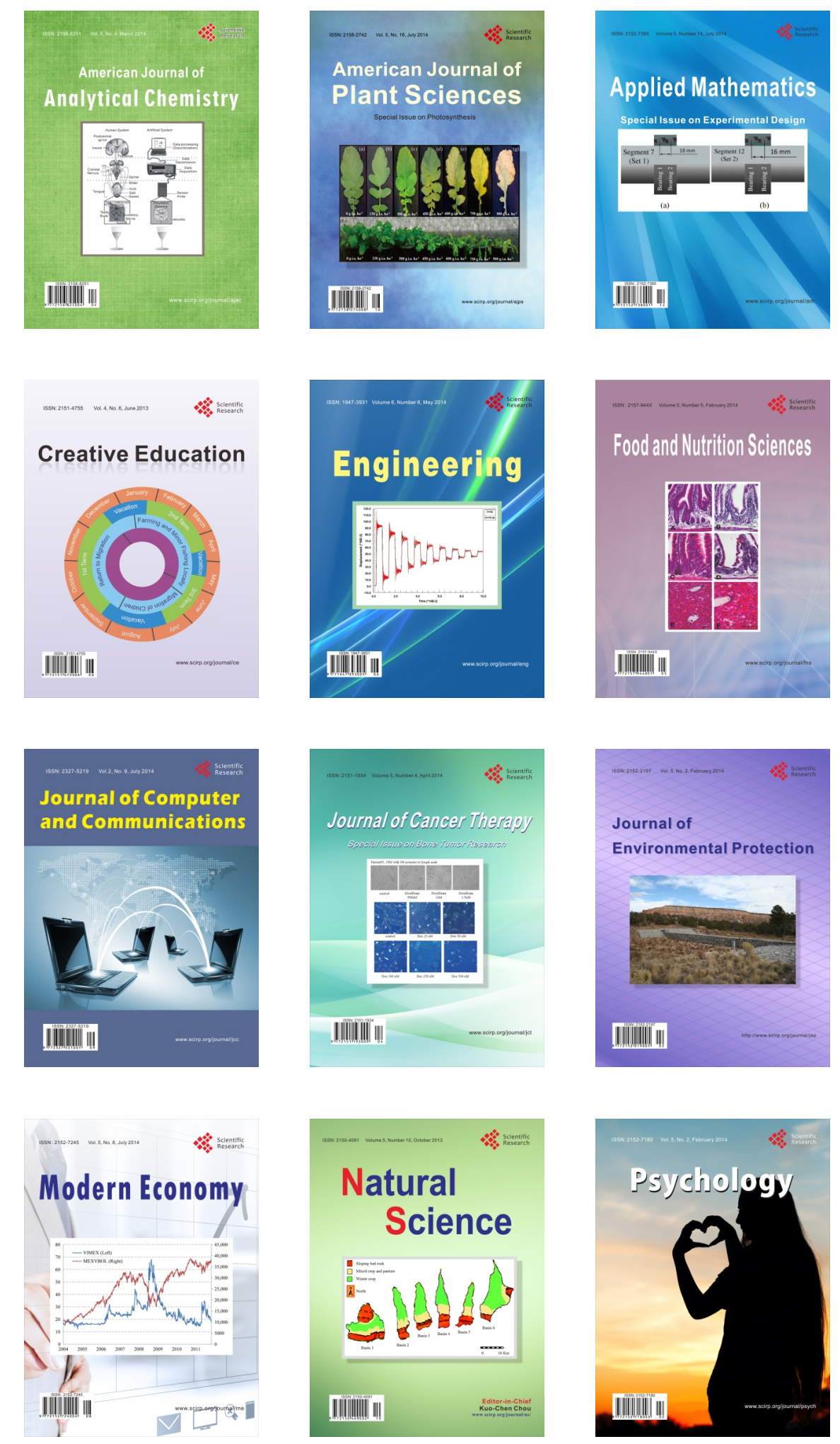